Published on Reviews in History (https://reviews.history.ac.uk)

\title{
Insanitary City: Henry Littlejohn and the Condition of Edinburgh
}

Review Number: 1654

Publish date: Thursday, 11 September, 2014

Author: Paul Laxton

Richard Rodger

ISBN: 9781859362204

Date of Publication: 2014

Price: $£ 25.00$

Pages: 480pp.

Publisher: Carnegie Publishing

Publisher url: http://carnegiepublishing.co.uk/shop/insanitary-city-h-d-littlejohn-and-the-report-on-the-sanitary-con of-edinburgh-1865/

Place of Publication: Lancaster

Reviewer: Tom Crook

In 1862, Henry Littlejohn was appointed to the newly created position of Medical Officer of Health (MOH) for Edinburgh. Three years later, he published a Report on the Sanitary Condition of Scotland's capital city, then home to more than 170,000 people. It is a remarkable document, not least because it was the first to grapple with the sanitary puzzle of Edinburgh on a comprehensive basis, from the inner wynds and slums of Canongate and Tron to the outer, more spacious suburbs of Morningside and Grange; from New Town, north of Princes Street, to Old Town, situated to the south. Indeed, it is remarkable that Littlejohn found the time to assemble his meticulous analysis, which he presented over 120 pages, plus an appendix of a further 70, given his multiple other roles. There were three at the time of writing the Report: city Police Surgeon, a role that he combined with that of $\mathrm{MOH}$; lecturer in Medical Jurisprudence at the Royal College of Surgeons, Edinburgh; and advisor to the Board of Supervision, Scotland's central Poor Law agency, established in 1845. In 1865, he was also father to five children; eight more would follow.

Co-authored and arranged by Paul Laxton and Richard Rodger, Insanitary City: Henry Littlejohn and the Condition of Edinburgh provides the first account of the genesis and reception of this landmark document, before Littlejohn's Report is presented in the form of a facsimile. So, context then text: this, of course, is the familiar format of works like this, whereby a well-known or lesser known (as in this case) text is appraised and placed in its historical setting, followed by the text itself. One thinks here, for instance, of M. W. Flinn's edition of what is perhaps the most famous sanitary report of the Victorian period, Edwin Chadwick's Report on the Sanitary Condition of the Labouring Population of Great Britain (1842), published as long ago as 1965. We might also mention George Godwin's Town Swamps and Social Bridges (1859) and The Bitter Cry of Outcast London (1883), both of which were by reprinted by Leicester University Press in the early 1970s, complete with introductory essays and appraisals by Anthony D. King and Anthony S. Wohl, respectively. $\underline{(1)}$

In some ways, Insanitary City follows in the historiographical tradition of these earlier introductory works, which were concerned to foreground the empiricism and industry of the leading authors, and their struggles to convince an ignorant and apathetic public. There is little interest here in recasting the humanitarian as the 
disciplinary, or in unearthing the rhetorical and political uses of contested sanitary-scientific knowledge, something evident in more recent assessments of Victorian public health, especially those of Chadwick's agenda as it emerged in the 1840s and 1850s.(2) Quite the contrary: among other instances, the authors note the 'thorough research and dispassionate analysis' that went into Littlejohn's Report and the way 'his expert knowledge convinced the council committee to trust their advisors and to shape policy on the basis of evidence rather than mere opinion' (p. 208). The book is partly a celebration of Littlejohn's achievements, which were indeed immense and extended much beyond his 1865 text. Hired in 1862, he retired as the city's MOH in 1908, making for 46 years of public service (p. 8).

Two qualities distinguish Insanitary City. The first is the depth and richness of historical recovery, which means that the book doubles as a brilliant introduction to urban governance in early and mid-Victorian Edinburgh more generally. Littlejohn's Report is the main event, so to speak; yet the authors push much beyond - or behind - the text, covering its immediate genesis in the 1860s, as well as what preceded and followed it. As Police Surgeon, Littlejohn no doubt possessed keen forensic sensibilities; and they are more than matched by the authors' meticulous research into the broader history of administrative struggle in which Littlejohn figured - the multiple agendas, agents and arguments - and which defined Victorian Edinburgh as a work-in-progress in sanitary terms.

The second is bound up with the first: the quality of production and the inclusion of multiple photographs, diagrams, maps and tables, besides the facsimile of the Report. It begins as it goes on: before the contents page has been reached, readers are treated to two maps of Edinburgh - one from a Post Office directory; the other from Littlejohn's Report - and a photographic portrait of the man himself, taken in 1859. And these pictorial pleasures continue, and do so in abundance, in places occupying whole pages, elsewhere supplementing the text in the margins. Carnegie Publishing Ltd has done a magnificent job. Perhaps the most striking images - and striking because of the technology involved - are three photographs of Edinburgh taken in the 1850s, one of a wynd in Cowgate (p. 21); another of a tall, terraced shop-front in the Grassmarket (p. 186); and a final one of Caledonian Distillery in Haymarket, snapped from a speeding train (p. 164). Other readers will no doubt find their own favourites; and there are many to choose from.

The first chapter is largely biographical, setting out Littlejohn's career and connections, of which there were many, extending later in life to voluntary roles on hospital boards and professional committees. Chapter two examines the ethos of 'medical policing' as it emerged in the first half of the 19th century, building on Edinburgh's enlightened, university-based connections to the Continent, especially to France and Germany. It is here where Laxton and Rodger partly seek to account for what they later dub Littlejohn's more 'holistic or interdisciplinary' approach to public health, one that took into account considerations of poverty and the 'wider social context' (p. 26, p. 156). The contrast here is with England's - and more especially Chadwick and his allies' - relatively restricted reading of 'public health' as a problem of sanitation and the provision of water and sewerage systems (pp. 32-4).

Chapters three to five deal more directly with the making, reception and impact of Littlejohn's Report, unpacking the civic tensions and muddled networks of policy-making into which it entered. Much as in English cities, mid-century Edinburgh was a confusing administrative patchwork. Up to the mid-1850s, the key public health body was the Police Commission established in 1805, plus a medley of conflicting, overlapping boards and committees that had developed thereafter. In 1856, the sanitary powers of the Police Commission were transferred to the Town Council. Crucially, only the year before Scotland had established its own civil registration system, meaning that access could now be had to reasonably accurate mortality data. Chapter six sets out the legacy of the Report and the progress that ensued in Edinburgh after 1865.

These chapters, especially chapters three to five, are difficult to summarise. The complexities that are recovered are immense and are testament to the scholarly and archival rigour of Insanitary City. More might be said about the shifting administrative structures, as well as the personalities and policies, politics and problems that are brought back to life in Insanitary City. Even Littlejohn's appointment in 1862 was a 'messy, contested affair, with foot-dragging masquerading as principled objection' (p. 91), write the authors, 
before detailing the process over the course of nine pages. Indeed, the book can also be read as a case study of the complexities of mid-Victorian urban governance. Little wonder that in Edinburgh, as in cities south of the border, there was a 'quest for organisational efficiency' (p. 192). Littlejohn was at once a product and a pioneer of just this quest.

Yet, if there was conflict in the council chamber and beyond, there was also consensus and coalitionbuilding, and one aspect this book sheds some much needed light upon is the role of the press as an agent that helped to facilitate Victorian sanitary reform (see especially the authors' comments on pp. 107-8). The proceedings of the Police Commission had earlier been reproduced - verbatim in some instances - in the daily press, supplemented by editorial commentary; and Littlejohn's Report was likewise given considerable publicity in this arena. The day after the Town Council received the Report in August 1865, the Evening Courant chivvied and encouraged: 'There is probably no other city in this kingdom now so well informed of what is needed to be done;' it declared, adding: 'and we trust our Town Council ... will now devote itself thoroughly to the needed reforms' (p. 103). This is but one of many instances that feature in Insanitary City. In their concluding comments, Laxton and Rodger describe Littlejohn as a 'networked operator', noting that his 'office was within a stone's throw of all three main Edinburgh newspapers and ... just 50 yards from the council chambers' (p. 224).

The Report itself is dealt with in chapter four, where the authors guide the reader through the main elements deemed ripe for reform by Littlejohn and the background to each. These extend from Edinburgh's byres (cowsheds), butchers and bakehouses and industrial pollution to water supply and sewerage systems and the disposal of dead bodies. At the same time, Littlejohn grappled with the problem of defining 'Edinburgh' as an object of sanitary inquiry, for like other cities it was defined differently according to different functions. For political and municipal purposes, it was divided into 13 wards; for census and civil registration purposes, into five districts; and for poor law purposes, into three principal parishes. Littlejohn, however, opted to divide Edinburgh into 19 districts, which reflected better, so he argued, the social composition of the population, degrees of poverty and demographic density, and the quality or not of sanitary amenities such as water supply (pp. 112-16). This is precisely how the Report opens, with a defence of its geographicalclassificatory schema, which is then followed by a district-by-district breakdown of birth and death rates; distributions of disease (of the brain and heart; phthisis, diphtheria and measles, among others); and population density. Before detailing the problems noted above, Littlejohn then dwells on some further elements that added to the sanitary condition of Edinburgh: common lodging houses (cheap hotels for the very poorest); philanthropic housing; pauperism and poor law dependency; and the elevation of the population above sea-level.

Laxton and Rodger rightly praise the integrity and empirical intensity of Littlejohn's Report - its 'methodological and statistical rigour' - which made for a 'first-class social investigation by a man with a penetrating analytical mind' and who was 'driven more by an adherence to the Hippocratic oath to relieve suffering than by a preoccupation with death and its causes' (p. 157); and he was indeed concerned just as much with recurrent sickness (morbidity) as he was with mortality. Similarly, he was concerned to account for both environmental and socio-economic factors (p. 162-3), something that distinguishes Littlejohn's report from Chadwick's of 1842: 'The language of the Report [Littlejohn's] departed fundamentally from the judgemental tone of Chadwick's Sanitary Report where character defects and a culture of blame often targeted the poor and the Irish' (p. 162). 
This much might be true and here, as elsewhere, the discussion is distinguished by its attention to detail. Even so, one might query another claim made of the text, in particular the suggestion that the 'breath-taking scale of Littlejohn's empirical undertaking itself is sufficient to mark it out as fundamentally different from that of earlier investigations of public health' (p. 157). Much depends on what is meant by 'fundamentally' and it is of course different: a particular city (Edinburgh); a particular year (1865); and a particular author; and Littlejohn's text does indeed offer some very particular, even holistic, emphases and diagnoses. Perhaps the authors are referring solely to the Scottish context and here they note the work of William T. Gairdner, a former tutor of Littlejohn's and from $1863 \mathrm{MOH}$ for Glasgow.

In terms of the form of the content, or its structure, however - or what, again, after John Pickstone, we might term Littlejohn's 'way of knowing' - the text is very much of a piece with the kinds of sanitary and social investigatory work that began to emerge in the 1830s and 1840s, at least in England.(3) One example is Sanitary Ramblings, an extensive study of London's Bethnal Green area published in 1848 and written by Hector Gavin, a member of the Health of Towns' Association and a Lecturer on Forensic Medicine and Public Health at Charing Cross Hospital (though in fact Gavin had earlier trained in Edinburgh).(4) Gavin begins by discussing the problem of how to divide up the parish for the purposes of his 'sketches and illustrations', eventually settling on the districts for discharging medical relief; and each district is dealt with in turn and described in detail. Gavin then sets out the problems, dedicating discrete sections to each including dwelling houses and lodging houses; the warming and ventilation of houses; and sewerage, interments, nuisances and water supply - before presenting mortality data and tables derived from the English registration system, which had earlier been established on a civil basis in 1837.

Gavin's text is peculiar, of course, and is not of the scale or rigour of Littlejohn's later report. Bethnal Green was then home to roughly 82,500 people and Ramblings extends only to 115 pages; and all kinds of further differences might be noted. Equally, other examples of might be given of this form of social-sanitary reportage, one that, arguably, dates back to James Phillips Kay's 1832 investigation of Manchester and the work of the Manchester Statistical Society, which in 1838 published what seems to have been the first largescale social survey of a single British city (Kay, too, incidentally, studied for his MD in Edinburgh).(5) The point is not to dispute Littlejohn's bravery or analytical brilliance, or even the novelty of the Report; only to suggest that Laxton and Rodger's claim that his report is 'fundamentally different' requires some qualification. In fact, one could argue it developed a mode of analysis that had existed for over 25 years.

This is a minor gripe, however. Between them, Laxton and Rodger and Carnegie Publishing have produced a remarkable book about a remarkable man and report. A final question: how should one read Insanitary City? In the preface, the authors suggest from beginning to end, or perhaps by moving back and forth between their own text and that of Littlejohn (p. xvi). Another approach is to start with Littlejohn's Report and then to go back to Laxton and Rodger's substantive and richly researched chapters. Simply because this way the reader obtains what is arguably the best experience to be had from Insanitary City: namely, a full sense of the dizzying multiplicity of local factors and forces that go into the making and reception of just one historical document, however neat and tidy it may appear - or reappear, as in this case - in print.

\section{Notes}

1. Report on the Sanitary Condition of the Labouring Population of Gt. Britain, by Edwin Chadwick, 1842, ed. M. W. Flinn (Edinburgh, 1865); The Bitter Cry of Outcast London; with leading articles from the Pall Mall Gazette of October 1883 and Articles by Lord Salisbury, Joseph Chamberlain and Forster Crozier, ed. Anthony S. Wohl (Leicester, 1970); Town Swamps and Social Bridges by George Godwin, ed. Anthony D. King (Leicester, 1971).Back to (1)

2. See especially Mary Poovey, 'Domesticity and class formation: Chadwick's 1842 Sanitary report', in her Making a Social Body: British Cultural Formation, 1830-1864 (Chicago, IL, 1995), pp. 115-31; and Christopher Hamlin, Public Health and Social Justice in the Age of Chadwick: Britain, 1800-1854 (Cambridge, 1998). Back to (2) 
3. In particular, one might argue these social-sanitary investigations partake of what Pickstone distinguishes as an 'analytical' way of knowing. John V. Pickstone, Ways of Knowing: A New History of Science, Technology and Medicine (Manchester, 2000). Back to (3)

4. Hector Gavin, Sanitary Ramblings: Being Sketches and Illustrations of Bethnal Green, a Type of the Condition of the Metropolis and Other Large Towns (London, 1848). Tristram Hunt, 'Gavin, Hector (1815-1855)', Oxford Dictionary of National Biography (Oxford University Press, 2006), online edn, May 2009 <http://www.oxforddnb.com.oxfordbrookes.idm.oclc.org/view/article/94168 [2] > [accessed 6 July 2014].Back to (4)

5. Kay's pamphlet is well-known; but in fact the Manchester Society's later report is deserving of attention, given its novel scale and nature. Report of a Committee of the Manchester Statistical Society: on the condition of the working classes, in an extensive manufacturing district, in 1834, 1835, and 1836 (London, 1838). Back to (5)

Source URL:https://reviews.history.ac.uk/review/1654

\section{Links}

[1] https://reviews.history.ac.uk/item/98705

[2] http://www.oxforddnb.com.oxfordbrookes.idm.oclc.org/view/article/94168 